\title{
屋外測定による再帰反射材の日射に対する再帰反射率推定 OUTDOOR MEASUREMENT OF SOLAR REFLECTIVE PERFORMANCE OF RETROREFLECTIVE MATERIALS
}

\author{
酒 井 英 樹*, 小林 春 奈**, 永村一雄***, 井川憲 男**** \\ Hideki SAKAI, Haruna KOBAYASHI, Kazuo EMURA \\ and Norio IGAWA
}

\begin{abstract}
The solar reflective performance of several retroreflective materials are evaluated by outdoor measurements. Their reflectances were derived from the quantity of heat energy received, which were calculated from temperature data. By correcting the measured data to fit the reflectivities of several non-retroreflective materials, the value of retroreflective component can be determined with an accuracy of about 1 percent, irrespective of measurement date. The measured retroreflective components are 5 and 13 percent for the bead-embedded type, 18 percent for the capsule-lens type, and 24 and 30 percent for the prism-array type.
\end{abstract}

Keywords: Retroreflection, Solar Reflectance, Heat Island, Reflected Heat, Outdoor Measurement 再帰反射，日射反射率，ヒートアイランド，照り返し，屋外測定

\section{1. はじめに}

再帰反射材とは，光源から入射された光を再び入射方向一反射す る性質（再帰反射性）を有する材料である。現在，この再帰反射材 は，夜間の視認性を高める目的で，交通標識の基板や衣料品のマー カーとして広く使われているが ${ }^{1,2)}$, 本研究では, これを建物外皮に 用いて，入射した日射を確実に天空方向へ返すことで，地表面での 日射受熱量を減らし，都市部で年々深刻化している夏場のヒートア イランド現象を抑制するという再帰反射材の新たな利用方法を検討

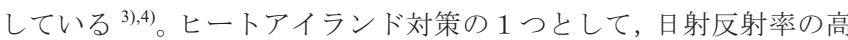
い塗料によって建物外皮を高反射化する方法があるが 5),6),7)，可視か ら近赤外域において再帰反射性を示寸材料を建物外皮に使うことで, どのような方向から入射した日射であっても確実に天空方向に跳秝 返すことができれば，適用した建物の受熱量を減らすだけでなく，

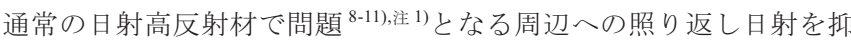
制することができると考えられる ${ }^{3), 4), 12) 。 ~}$

再帰反射材には，プリズムの反射や球状レンズの屈折を利用する などの発現機構があるが，その反射性能の評価は，これまで視認性 の観点から行われており注 2), 日射に対寸る反射性能を評価した報告 はほとんど見受けられない 33,4),12)。現時点では, 日射反射の観点から 設計・製造された再帰反射材料は存在せず，交通標識用などとして 夜間の視認性を向上する目的での夕開発されている。しかし，視認 性のよいものが必ずしも日射反射に適しているとは限らないことか ら乼 3 ），再帰反射材の日射に対寸る反射性能の評価を行うことは，今 後, 再帰反射材を日射照り返し抑制効果を持つ建材として実用化し,
さらに，その目的に適した材料開発を行うために必要である。

筆者らは前報 ${ }^{3), 4}$ において, 再帰反射材の照り返し抑制効果を実証 するとともに，日射反射の観点から必要とされる再帰反射成分の測 定法の検討を行った。しかし, 測定法の妥当性の検証を主な目的と したため，同じ条件で繰り返し実験することができるように，照射 源としては，実際の日射ではなく赤外線ランプを用いていた。

そこで，本論文では，標識用として市販されている 5 種類の再帰 反射材を屋外に設置し，実際の日射に対寸る再帰反射率を初めて測 定した。屋外測定では，測定日の気象条件によって，反射率の算出 值がばらつくが ${ }^{13)}$ ，日射反射率が既知の再帰反射性のない材料を元 に補正することで, 測定日によらず精度よく再帰反射率を推定する ことができた。その補正方法と，日射量など反射率を算出するため に必要となる測定項目，および，実測結果について報告する。

\section{2. 測定方法}

\section{1 測定方法の概要}

建築材料の日射反射率の測定法としては，（1）日射照射時の表面 温度上昇から材料面の受熱量を推定し，入射日射量との比較から反 射率を算出する (温度測定)，（2）日射計で入射日射量，反射日射量 を同時測定し，その比率から反射率を算出する (アルベド測定)，(3) 分光光度計で材料面の分光反射率を測定し，日射分光分布を掛け合 わせて反射率を算出する (分光測定)，などが考えられる。

既報 ${ }^{13)}$ で論じたように（1）の温度測定と（2）のアルベド測定で 得られる反射率は，測定時の日射の状態に依存してしまうため，正

本論文は, 日本建築学会学術講演梗概集 D2, pp.113-114，2007.8を基にしている。

* 大阪市立大学大学院生活科学研究科 講師 - 博士 (理学) Lecturer, Graduate School of Human Life Science, Osaka City Univ., Dr. Sci.

* 大阪市立大学大学院生活科学研究科前期博士課程 大学院生

*** 大阪市立大学大学院生活科学研究科 教授.工博

**** 大阪市立大学大学院生活科学研究科 教授. 博士 (工学)

Graduate Student, Graduate School of Human Life Science, Osaka City Univ.

Prof., Graduate School of Human Life Science, Osaka City Univ., Dr. Eng. Prof., Graduate School of Human Life Science, Osaka City Univ., Dr. Eng. 
確な評価には（3）の分光測定が望ましい。しかし，再帰反射材に対 しては, 状況が異なる。つまり, 分光光度計を用いて光学的に反射 率を測定する場合 ${ }^{14), 15)}$, 入射光軸に完全に一致した場所に受光部を 置くと, 入射光を妨げることになるため, 再帰反射率 (Retroreflection, $\left.\rho_{\mathrm{Ret}}\right)$ は測定できない。分光測定で得られるのは, 再帰反射以外の 反射成分，つまり，鏡面反射率（Specular reflection, $\rho$ Spe $)$ と拡散 反射率（Diffuse reflection， $\rho$ Dif）である。一方，温度測定では，吸 収された熱量から反射率を算出するため，鏡面反射，拡散反射，再 帰反射すべてを含んだ全反射率（Total reflection, $\rho_{\mathrm{T}}$ ）が得られる。

以上のことから，再帰反射率 $\rho$ Ret は直接測定することはできない が, (1)の温度測定で求めた全反射率 $\left(\rho_{\mathrm{T}}=\rho_{\mathrm{Spe}}+\rho_{\text {Dif }}+\rho_{\text {Ret }}\right)$ から, (3)の分光測定で求めた鏡面および拡散反射率（ $\left.\rho_{\mathrm{Spe}}+\rho_{\mathrm{Dif}}\right)$ を差し 引くことで, 再帰反射率 $\rho_{\text {Ret }}$ の值を間接的に求めることができる ${ }^{3), 4)}$

本論文においても, この測定手順, つまり, 分光光度計による分 光測定（2.2 節）と屋外暴露時の温度測定（2.3 節）とを併用するこ とで, 再帰反射率の測定を行う。ただし, 測定精度を担保するため, 大気の状態によって刻々と変化する日射量を含む気象要素を総合的 に測定するとともに，同じ気象条件下で，再帰反射性を持たない塗 膜試料（分光測定で正確に反射率が測定できる）についても温度測 定を行い，それら試料の日射反射率の值を使って再帰反射材の補正 を行う (3.2 節)。

\section{2 分光光度計による分光測定}

試験試料には，標識用として市販されている再帰反射材 5 種（表 1 の試料番号 6 - 10）と，日射反射率の校正用に反射率の異なる塗膜 5 種(表 1 の試料番号 1 - 5) の計 10 種類を用いた。各試料の詳細は,

表 1 の備考欄および注 2 を参照のこと。

まず，各試料の鏡面および拡散分光反射率 $\rho_{\mathrm{Spe}}(\lambda)+\rho_{\mathrm{Dif}}(\lambda)$ と, 鏡面成分を光学吸收体で取り除いた拡散反射成分だけの分光反射率 $\rho_{\operatorname{Dif}}(\lambda)$ とを注 ${ }^{4}$, 文献 13 の測定手順に従って, 積分球付属分光光度 計（島津製作所 UV-3600, 積分球 LISR-3100, 内径 $150 \mathrm{~mm} \phi, 7^{\circ}$ 入 射(垂直入射を $\left.0^{\circ}\right)$ ) により測定した。測定波長は， $\lambda=300-2500 \mathrm{~nm}$ (間隔 $5 \mathrm{~nm}$ ), 測定温度は約 $23^{\circ} \mathrm{C}$ (室温) であった。分光光度計の 反射率校正は，米国 Labsphere 社製，標準反射板 Spectralon（反射率 $99 \%$ ）を用いた。鏡面および拡散分光反射率 $\rho_{\mathrm{Spe}}(\lambda)+\rho_{\mathrm{Dif}}(\lambda)$ の測 定結果を図 1 ( (a)塗膜 5 種，(b)再帰反射材 5 種）に示す。

つぎに，測定した鏡面成分を含む分光反射率に板ガラス類の日射 反射率算出の際に用いる JIS R 3106 付表 2 の直達日射の分光分布 ${ }^{16)}$ を掛け合わせて求めた鏡面および拡散日射反射率 $\rho$ Spe $+\rho_{\text {Dif }}$ ，表 1 の第 2 列に，拡散成分のみの分光反射率に同じく日射分光分布を 掛けて算出した拡散日射反射率 $\rho$ Dif

表 1 各試験試料の分光測定による日射反射率（JIS R 3106 ${ }^{16)}$ )

\begin{tabular}{|c|c|c|c|c|}
\hline 試料 & $\rho$ Spe $+\rho \operatorname{Dif}[\%]$ & $\rho \mathrm{Dif}[\%]$ & $\rho$ Spe[\%] & 備考(製品名称) \\
\hline 1: 塗膜(高反射白) & 84.8 & 83.2 & 1.6 & 太陽熱高反射塗料白色 \\
\hline 2: 塗膜(高反射灰) & 64.1 & 62.5 & 1.6 & 太陽熱高反射塗料灰色 \\
\hline 3: 塗膜(高反射黒) & 35.0 & 33.2 & 1.8 & 太陽熱高反射塗料黒色 \\
\hline 4: 塗膜(一般白) & 74.7 & 72.5 & 2.2 & 一般塗料白色 \\
\hline 5: 塗膜 (一般黒) & 7.2 & 4.9 & 2.3 & 一般塗料白色 \\
\hline 6: 再帰材 (プリズム) & 48.2 & 43.8 & 4.5 & N社プリズム型超高輝度 \\
\hline 7: 再帰材 (カプセル) & 42.1 & 36.6 & 5.5 & N社カプセルレンズ型高輝度 \\
\hline 8: 再帰材 (封入) & 55.6 & 51.9 & 3.7 & N社封入レンズ型 \\
\hline 9: 再帰材 (封入) & 62.2 & 57.5 & 4.7 & U社封入レンズ型広角タイプ \\
\hline 10: 再帰材 (プリズム) & 47.5 & 36.0 & 11.6 & S社プリズム型超高輝度 \\
\hline
\end{tabular}
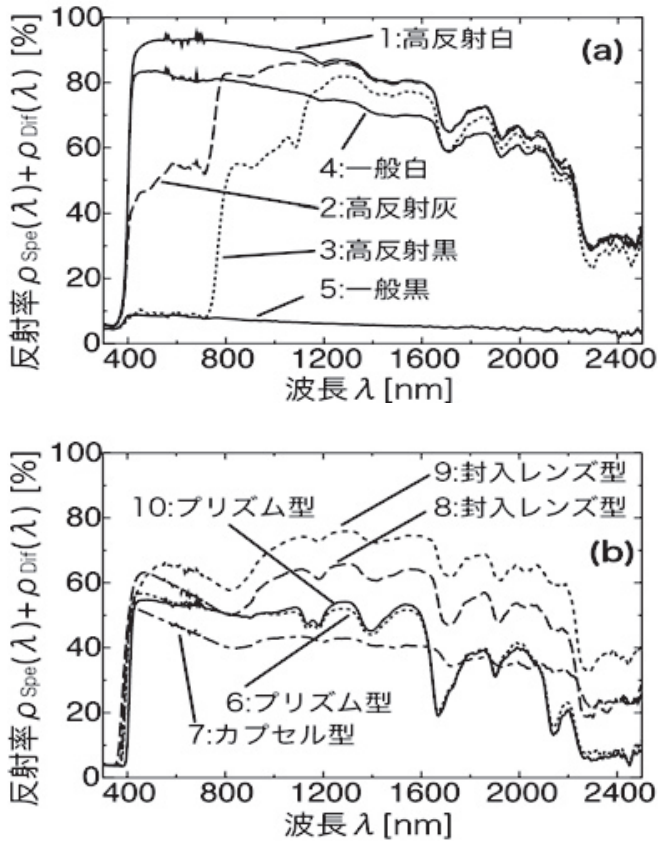

図 1 分光光度計 $\left(7^{\circ}\right.$ 入射，積分球受光）で測定した分光反射率

列は，両者の差から計算した鏡面日射反射率 $\rho_{\mathrm{Spe}}$ である。ここで， 実際の日射には天空成分も含まれ, さらに，気象条件によってその 分光分布は時々刻々と変化するため ${ }^{17), 18)}$, 㛜密には, 試料の設置場 所や測定時の気象条件を特定しなければ日射反射率は定まらない。 しかし，材料の評価指標としては，標準的な日射分光分布を決める ことが必要である ${ }^{13)}$ 。そこで, 建築材料の評価に広く用いられてい ること，さらに，再帰反射材の利用目的としては，主に直達日射を 想定していることから，本論文では，JIS R 3106 に定められた直達 日射に対する反射率を基準值と定め，表 1 の值を使って，温度測定 から求めた反射率の補正を行うこととする。

\section{3 屋外における温度測定}

屋外測定の実施は以下の通りである。各試料（試料面寸法 $75 \mathrm{~mm}$ $\times 70 \mathrm{~mm}$ ) を, 大阪市立大学生活科学部棟屋上（北緯 $34^{\circ} 36^{\prime}$ ，東 経 $135^{\circ} 30^{\prime}$ ）に，測定日の南中時刻に直達日射が約 7 度で入射す るよう南方向きに傾斜させて設置した。（7 度にした理由は，分光測 定に用いた分光光度計の入射条件が 7 度に固定されているためであ る。一般に, 反射率は, 入射角に依存するため ${ }^{5), 19)}$, 分光測定と温 度測定の結果を比較するには，入射角を一致させる必要がある。）各 試料の裏面は，厚さ $30 \mathrm{~mm}$ の断熱材（発泡スチロール）を 2 枚貼り 合わせたもので断熱し, 試料ごとに, 試料裏面中央部 1 点と断熱材

(30mm 厚) を 1 枚はさんだ 1 点の計 2 点の温度を, $\mathrm{T}$ 型熱電対で 測定した。気象条件として, 全天・天空日射量, 法線面直達日射量,

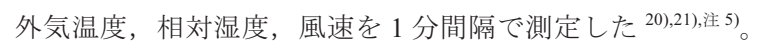

実験期間は 2006 年 10 月から 2007 年 2 月であり, このうち, 南中 時刻前後に穏やかで快晴となった，11月 29 日，12月 4 日，12月 5 日，1月29日を測定日とした。

つぎに，日射照射時の試料面での熱収支は，定常状態を仮定し，1 次元の熱流方向における式で計算した。

$$
J_{i} \cdot\left(1-\rho_{\text {temp }}\right)=q_{s}+q_{c v}+q_{c d}
$$




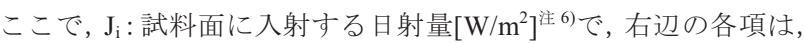
以下の式に測定值を代入して計算した。

まず，試料面からの長波長放射量 $\mathrm{q}_{\mathrm{s}}\left[\mathrm{W} / \mathrm{m}^{2}\right]$ は,

$$
q_{s}=-F_{s a} \varepsilon_{s} \varepsilon_{a} \sigma T_{a}^{4}-F_{s w} \varepsilon_{s} \varepsilon_{w} \sigma T_{w}^{4}+\varepsilon_{s} \sigma T_{s}^{4}
$$

ただし， $\mathrm{F}_{\mathrm{sa}}$ ：試料面から大気をみる形態係数 $\left(1+\cos \theta_{\mathrm{s}}\right) / 2$,

$\mathrm{F}_{\mathrm{sw}}$ : 試料面から地物をみる形態係数 $\left(\mathrm{F}_{\mathrm{sw}}=1-\mathrm{F}_{\mathrm{sa}}\right), \varepsilon_{\mathrm{s}}$ : 試料面の放 射率, $\varepsilon_{\mathrm{a}}$ : 大気の射出率, $\varepsilon_{\mathrm{w}}$ : 地物の放射率, $\mathrm{T}_{\mathrm{a}}$ : 外気温 $[\mathrm{K}]$,

$\mathrm{T}_{\mathrm{w}}$ : 地物表面温度 $[\mathrm{K}], \mathrm{T}_{\mathrm{s}}$ : 試料面温度 $[\mathrm{K}]$, とする。

つぎに，対流熱量 $\mathrm{q}_{\mathrm{cv}}\left[\mathrm{W} / \mathrm{m}^{2}\right]$ は,

$$
q_{c v}=\alpha_{c}\left(T_{s}-T_{a}\right)
$$

ただし， $\alpha_{\mathrm{c}}$ : 対流熱伝達率 $\left[\mathrm{W} /\left(\mathrm{m}^{2} \cdot \mathrm{K}\right)\right]$ とし, ユルゲス（Jürges）の 式（風速 $\mathrm{v} \leqq 4.9[\mathrm{~m} / \mathrm{s}]$ のとき $\alpha_{\mathrm{c}}=5.6+3.9 \mathrm{v}, \mathrm{v}>4.9 \mathrm{~m} / \mathrm{s}$ のとき $\left.\alpha_{\mathrm{c}}=7.2 \mathrm{v}^{0.78}\right)$ で計算する ${ }^{22), 23) 。}$

最後に, 伝導熱量 $\mathrm{q}_{\mathrm{cdd}}\left[\mathrm{W} / \mathrm{m}^{2}\right]$ は,

$$
q_{c d}=\frac{\lambda}{d}\left(T_{s}-T_{d}\right)
$$

ただし， $\lambda$ : 断熱材の熱伝導率 $[\mathrm{W} / \mathrm{m}], \mathrm{d}$ : 断熱材厚み $[\mathrm{m}], \mathrm{T}_{\mathrm{d}}$ : 断熱 材面の温度 $[\mathrm{K}]$, とする。

以上の值を（1）式に代入して, 未知数である日射反射率 $\rho_{\mathrm{temp}}$ (温 度測定による全反射率）を求める。

\section{3. 結果と考察}

\section{1 測定結果}

測定を行った 4 日間の天空日射および法線面直達日射の日変化を 図 2 に示寸 (全天日射量は省略)。分析には, 各測定日の南中時刻を 含む 1 時間（図 2 の正午前後の 2 本の垂直線間）の日射量の平均值 を使用した。表 2 に全天日射量 $\left(\mathrm{J}_{\mathrm{H}}\right)$, 天空日射量 $\left(\mathrm{J}_{\mathrm{SH}}\right)$, 法線面直 達日射量 $\left(\mathrm{J}_{\mathrm{DN}}\right)$ の 1 時間平均と, それらを( $\left.\mathrm{A} 1\right)$ 式注 ${ }^{6}$ に代入して 算出した試料面に入射する日射量 $\left(\mathrm{J}_{\mathrm{i}}\right)$ を示す。

外気温湿度，風速（表 2)，および，各試料面温度も同様に，南中 時刻を含む 1 時間の平均をとり，それらの值を（2）-（4）式に代入 し, 長波長放射量 $\mathrm{q}_{\mathrm{s}}$, 対流熱量 $\mathrm{q}_{\mathrm{cv}}$, 伝導熱量 $\mathrm{q}_{\mathrm{cd}}$ を算出した。

最後に，これらの值を（1）式に代入して，測定日ごとの試料の日 射反射率 $\rho$ temp を求めた。表 3 に温度測定に基づく日射反射率 $\rho$ temp を, 2.2 節で求めた分光反射率から求めた日射反射率 $\rho_{\mathrm{Spe}}+\rho_{\mathrm{Dif}}$ とと もに示す。

表 3 を見ると, 塗膜, 再帰反射材ともに, 温度測定から求めた日 射反射率 $\rho$ temp は，11/29 と $12 / 4$ の值はほぼ一致しているが，残り 2 日とは一致しない。日射反射率が測定日によって変動する原因とし

\begin{tabular}{|c|c|c|c|c|c|c|}
\hline \multirow{2}{*}{ 測定日 } & \multirow{2}{*}{ 時刻 } & \multicolumn{3}{|c|}{ 平均日射量 $\left[\mathrm{W} / \mathrm{m}^{2}\right]$} & \multirow{2}{*}{$\begin{array}{l}\text { 計算值* } \\
\text { 入射 Ji }\end{array}$} & \multirow{2}{*}{$\begin{array}{c}\text { 平均風速 } \\
\mathrm{v}[\mathrm{m} / \mathrm{s}]\end{array}$} \\
\hline & & 全天JH & 天空JSH & 直達JDN & & \\
\hline $2006 / 11 / 29$ & $11: 17-12: 17$ & 579.1 & 183.7 & 677.1 & 939.5 & 1.78 \\
\hline $2006 / 12 / 4$ & $11: 19-12: 19$ & 568.0 & 87.1 & 841.4 & 986.6 & 3.09 \\
\hline $2006 / 12 / 5$ & $11: 19-12: 19$ & 472.6 & 176.3 & 515.1 & 761.2 & 1.21 \\
\hline $2007 / 1 / 29$ & $11: 42-12: 42$ & 638.0 & 129.9 & 778.8 & 980.6 & 2.69 \\
\hline
\end{tabular}
ては，比較的安定した晴天日を選んで測定したものの，熱収支を定

表 2 平均日射量（実測および計算值）と平均風速

*測定值から (A1) 式を使って計算した試料面への入射日射量
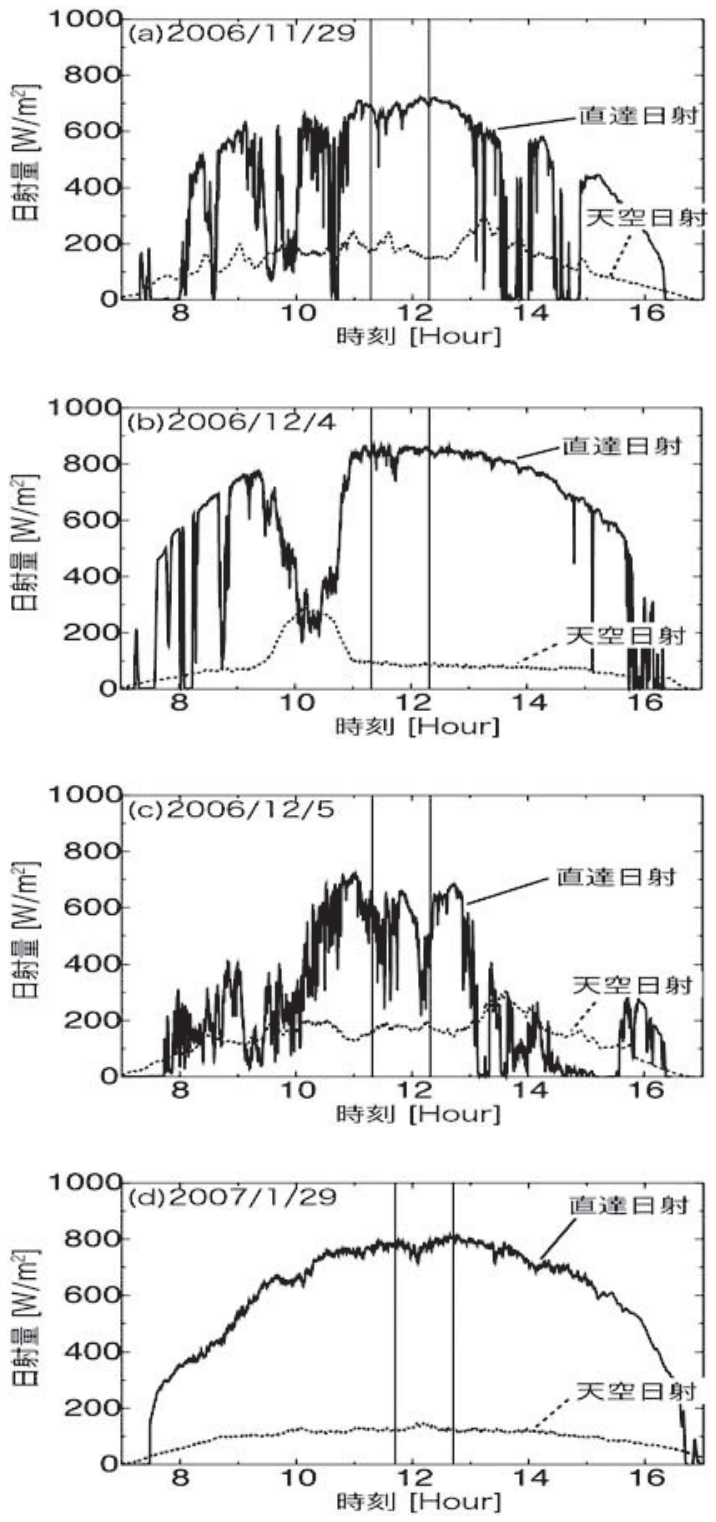

図 2 天空日射量および法線面直達日射量の日変化

常状態かつ 1 次元と仮定していることや，測定日によって日射量や 風速など気象条件が異なることに起因する誤差, さらに, 実際に日 射の分光分布が変動しているなど ${ }^{13), 17), 18)}$, 様々な要因が考えられ,

\begin{tabular}{|c|c|c|c|c|c|}
\hline \multirow{2}{*}{ 試料 } & \multirow{2}{*}{\begin{tabular}{|c} 
分光測定 $[\%]$ \\
$\rho$ Spe $+\rho$ Dif
\end{tabular}} & \multicolumn{4}{|c|}{ 温度測定 $\rho$ temp [\%] } \\
\hline & & $11 / 29$ & $12 / 4$ & $12 / 5$ & $1 / 29$ \\
\hline 1: 塗膜(高反射白) & 84.8 & 79.5 & 79.3 & 75.2 & 76.8 \\
\hline 2: 塗膜 (高反射灰) & 64.1 & 66.0 & 66.2 & 62.4 & 63.7 \\
\hline 3: 塗膜 (高反射黒) & 35.0 & 48.0 & 49.4 & 43.9 & 47.5 \\
\hline 4: 塗膜(一般白) & 74.7 & 73.2 & 73.3 & 68.7 & 71.3 \\
\hline 5: 塗膜 (一般黒) & 7.2 & 27.9 & 29.4 & 22.8 & 28.1 \\
\hline 6: 再帰材 (プリズム) & 48.2 & 75.0 & 75.3 & 71.3 & 72.7 \\
\hline 7: 再帰材 (カプセル) & 42.1 & 64.0 & 63.6 & 59.1 & 61.6 \\
\hline 8: 再帰材 (封入) & 55.6 & 68.8 & 69.4 & 65.1 & 66.9 \\
\hline 9: 再帰材 (封入) & 62.2 & 67.9 & 68.4 & 64.5 & 65.9 \\
\hline 10: 再帰材 (プリズム) & 47.5 & 70.6 & 70.9 & 66.5 & 68.9 \\
\hline
\end{tabular}
その特定は難しい。ただし，このような変動は，屋外測定でよく報

表 3 分光測定および温度測定に基づく試料の日射反射率 
告される現象である。そこで，これを回避するために，日射反射率 が既知の試料を同時に測定し，それらの值を参照することで，試験 試料の日射反射率を補正して標準的な日射に対する反射率を推定す る簡易測定法が屋外測定では用いられる ${ }^{5}$ 。

本論文の実験結果について, 表 3 の值を図示すると（図 3), 測定 日ごとの変動は規則的で試料間の相対的な位置関係は保たれている ことが分かる。よって, 測定日ごとに統制された条件で測定できて おり, 反射率が既知の試料に基づいて補正をすることで測定日によ らない日射反射率を推定することが可能であると考えられる。次節 で，正確な日射反射率が分光測定で求められる塗膜試料を反射率が 既知の参照試料として用いることで, 再帰反射材の日射反射率の補 正を行う。なお，図 3 において，塗膜試料（番号 1 - 5 , 破線）の測 定日ごとの日射反射率 $\rho$ temp の試料間の相対的な関係は, 分光測定か ら求めた日射反射率に対しても保たれているが，再帰反射試料（番 号 6-10, 実線) では, 相対的な位置関係が変わり, また, 試料番 号 9 を除き注7), 分光測定から求めた日射反射率が極端に低下してい る。これは, 2.1 節で説明したように, 光学的な手段である分光測 定で求めた反射率には，入射光軸の方向に反射される再帚反射成分 が含まれないためであり，この目減りした反射分が，再帰反射成分 に相当すると考えられる。よって, 塗膜試料の反射率を元に補正を 行うことで，再帰反射試料の正確な日射反射率が推定できるだけで なく, それらを, 表 1 の再帰反射材の分光測定值と比較することで, 分光光度計で捉えることができない再帰反射成分（再帰反射率）を 算出することが可能となる ${ }^{3), 4)}$

\section{2 日射反射率および再帰反射率の推定}

表 3 の結果を, 横軸を温度測定による日射反射率 $\rho_{\text {temp }}$, 縦軸を分 光測定から求めた日射反射率 $\rho$ Spe $+\rho_{\text {Dif }}$ としたグラフを図 4 に示寸。 4 日間とも 5 種の塗膜試料（○で表示）が，ほぼ直線上に位置して いることから, 測定日ごとに, これら 5 種の塗膜試料の $\rho$ Spe $+\rho$ Dif を $\rho_{\text {temp }}$ から推測する式を直線回帰（最小二乗法）で求めた。得られ た回帰直線を実線で示寸 (図 4)。また, 図の枠内にその回帰式 $\rho_{\mathrm{fit}}$ と $\mathrm{R}^{2}$ 值を示寸。各測定日とも $\mathrm{R}^{2}$ 值は 0.998 以上で， $\rho$ temp から精度 よく日射反射率（全反射率）を推定することができている。

一方, 図 4 において，再帰反射試料（○で表示）は，温度測定に 基づく反射率 $\rho_{\text {temp }}$ に含まれている再帰反射成分が, 分光測定の反射 率 $\rho_{\mathrm{Spe}}+\rho_{\mathrm{Dif}}$ には含まれていないことから, 回帰直線の下側に位置 している。測定日ごとに $\rho_{\text {temp }}$ の值を回帰式に代入し, 得られる值が

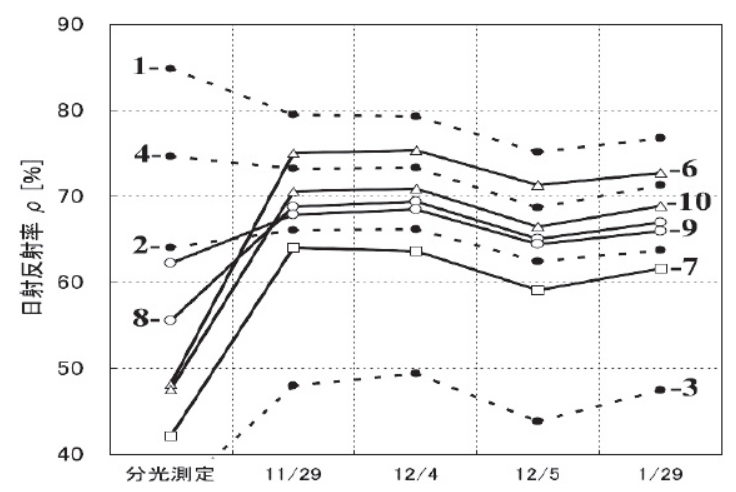

図 3 分光測定および温度測定に基づく試料の日射反射率 (図中の数字は試料番号, 再帰反射材は実線, 塗膜は破線。)

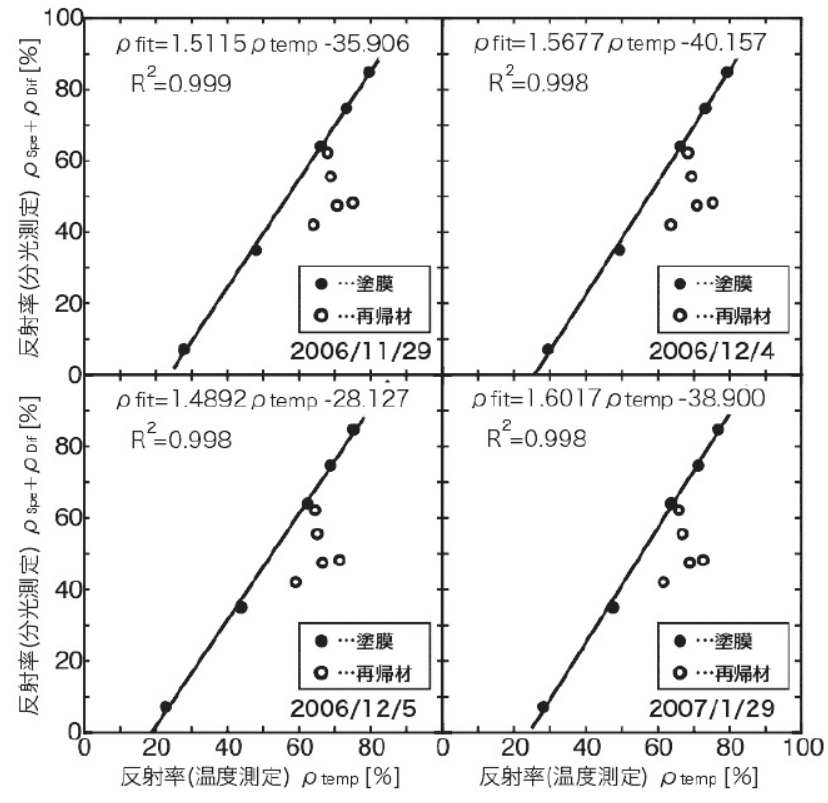

図 4 温度測定に基づく日射反射率 $\rho_{\text {temp }}$ と分光測定 に基づく日射反射率 $\rho_{\text {Spe }}+\rho_{\text {Dif }}$ との関係

再帰反射成分を含む全反射率である。このようにして求めた推定日 射反射率 $\rho_{\text {fit }}$ 表 4 に示寸。表 4 中段の “温度測定 $\rho_{\text {fit }}$ (補正)”欄 の值が, 推定された再帰反射材の全反射率である。温度測定から直 接求めた反射率 $\rho$ temp は, 測定日によって変動しているが, このよう な補正を施すことで, 測定日によらずほぼ一定（1\%程度の範囲）の 值を得ることができた。日射反射率が $1 \%$ 程度の精度で推定できれ ば，建築材料の評価としては十分な精度であると考えられる。

ただし,(3)式の対流熱伝達率は風速による影響を受けやすく22),23), 風速が大きくなると誤差要因となる。今回の実験条件は，4 日間と も平均風速が $3[\mathrm{~m} / \mathrm{s}]$ 程度以下であった (表 2 の最右列)。風速がこれ より大きくなると, 測定精度が低下する可能性がある。

表 4 日射反射率および再帰反射率の回帰式による推定

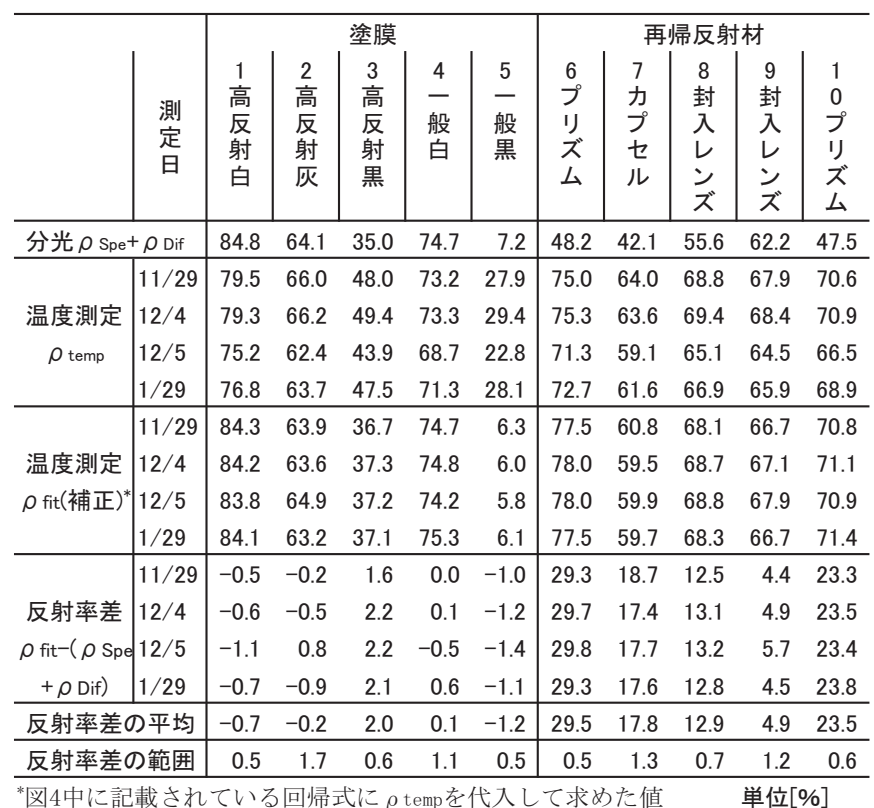


最後に，全反射率 $\rho_{\text {fit }}$ （補正）から鏡面および拡散反射率 $\rho_{\mathrm{Spe}}+$ $\rho_{\text {Dif }}$ 差し引くことで, 分光測定では測定できない再帰反射率を算 出した。表 4 下段の “反射率差” の值をみると, 試料番号 1 - 5 の塗 膜試料は, ほぼ $0 \%$ であるが, 試料番号 6 - 10 の再帰反射試料は, $5 \%$ から $30 \%$ 程度となっており, これが, 今回求めた再帰反射率 $\rho_{\text {Ret }}$ である。温度測定による全反射率 $\rho_{\mathrm{fit}}$ （補正）と同じく, 測定日間 の差は小さく（試料番号 7 の $1.3 \%$ が最大), 測定日によらず精度よ く推定できている。よって, 以下, 4 日間の平均値（表 4 下段の “反 射率差の平均”）を使って議論する。

再帰反射性の発現方式別に反射率を見ていくと, 試料番号 6 と 10 のプリズム型再帰反射材の再帰反射率が， $29.5 \% ， 23.5 \%$ と高く， つぎに，試料番号 7 のカプセルレンズ型が， $17.8 \%$ ，さらに，試料 番号 8 と 9 の封入レンズ型が, $12.9 \%, 4.9 \%$ と続く。この傾向は, 視認性の観点からの評価である再帰反射係数注 ${ }^{2)}$ の優劣とほぼ一致 している。すなわち, 視認性に関する一般的な傾向として, 再帰反 射機構のうち, 全反射を利用したプリズム型の再帰反射性能が高く, ガラスビーズを空気層で包むことで，ビーズのレンズ効果を最大限 利用したカプセルレンズ型がそれに続き, ガラスビーズを樹脂に埋 め込む封入レンズ型が一番性能が低いとされているが，今回の測定 では，日射反射に関しても同様の傾向が見られた。

\section{3 今後の課題}

本論文で使用した再帰反射材は，標識用として視認性の観点から

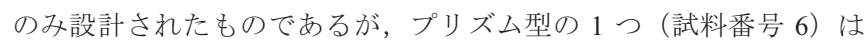
入射した日射のうち，30\%近くを入射した方向に返しており，これ をそのままビル壁面などの外皮に使用しても，十分な日射照り返し 抑制効果があると考えられる。ただし，表 1 第 4 列に示すように塗 膜に比べると，鏡面反射率 $\rho$ spe は大きくなっている。これは，今回 使用した再帰反射材は，標識用として，文字等を印刷できるように なめらかな樹脂で表面がコーティングされており, 多少光沢がある ためと考えられる。試料番号 10 を除けば，鏡面反射率は，高々数％ であり, 照り返しの総量としては小さい。よって, 都市のスケール で見れば，日射受熱量の抑制の効果はあると考えられる。しかし， 鏡面反射光は一点に集中寸るため, 光害となる恐れがある。また, 日射に限らず，自動車のヘッドライトなどの光も再帰反射してしま うため, ビル壁面のような大面積で使用すると夜間の視認性を阻害 寸るなどの弊害も起こりうる。よって, 今後, 再帰反射材を, 照り 返し抑制建材として実用化していくためには，反射防止膜で鏡面反 射を抑制したり，目に見えない近赤外域のみで再帰反射性を示し， 可視域では拡散性反射させたり寸るなどの改良が必要であろう。

また，再帰反射材は，レンズの屈折を利用寸るなど表面に複雑な 構造をもつため, 塗膜など拡散性の高い反射面と比べて入射角依存 性が高いと考えられる。本論文では, 使用した分光光度計の入射角 が 7 度に固定されている制約から，7 度入射時の反射率の測定を行 ったが，太陽の位置が季節，時間によって変わるため，日射方向は 刻々と変化する。よって, 今後, 建材としての性能評価を包括的に 行うには, 反射率の入射角依存性を評価する必要がある注7)。

\section{4. まとめ}

本論文では，照り返し抑制効果が期待できる再帰反射材料につい て, その基本性能である日射に対する再帰反射率の算出方法を提案
し，5 種類の再帰反射材料について, 実測を行った。屋外測定では 測定日の気象条件の違いによって, 日射反射率の算出值がばらつく が，日射反射率が既知の材料を元に補正をすることで，測定日によ らず精度よく（風速が小さければ，反射率 $1 \%$ 程度の範囲で）再帰 反射率を推定することができた。本論文で実施した測定および補正 方法は, 今後, 再帰反射材を照り返し抑制建材として開発していく 上で，有効な評価手法となりうる。

\section{謝辞}

本論文の一部は平成 19 年度科学研究費補助金（基盤研究(C), 課 題番号:19560578，代表:酒井英樹）およびトステム助成(No.07-55, 代表:永村一雄)の援助を受けた。記して謝意を表する。

注

注 1）日射反射率の高い叙料を適用した屋根・屋上面は，屋上緑化とともに クールルーフと称され，周りに高い構造物がなければ反射日射を天空へ返 すことができることからすでに実用化されている。しかし，周りに高い建 物がある場合や，壁面を高反射化する場合は，たとえ拡散性の高い塗膜で あっても，一定の割合で反射日射が隣接する建物や道路に吸収されるため, 周辺を高温化してしまう恐れがある ${ }^{8-11)}$ 。高反射材を適用した建物単体に対 する効果を否定するものではないが，天空率は小さくとも直達日射が到達 する面（例えば，高層ビル群を通過する東西道路に面したビルの南側壁面 など）に，通常の高反射材を適用すると，天空率が小さいほど，反射日射 が天空に返ることなく，周りの建物への照り返しとなる。これに対して， 再帰反射材は, 天空率が小さく拡散反射では大部分が周辺の建物に吸収さ れてしまうような箇所であっても，入射した日射を確実に天空方向（太陽 の方向）一返すことができるという利点がある ${ }^{3), 4,12)}$ 。再帰反射材は，低層 面や壁面など照り返しが問題となって現在の高反射材の使用には難のある 箇所にも使用できるため, 高反射化の適用範囲をさらに広げることができ ると考えられる。

注 2）再帰反射材の反射性能の評価法には 2 つの日本工業規格 ${ }^{11,2)}$ があるが, これらは，入射光軸から $12^{\prime} ， 20^{\prime}$ 及び $2^{\circ}$ とわずかにずれた角度から観 測した場合の単位照度当たりの反射輝度である再帰反射係数 $\left[\mathrm{cd} /\left(\mathrm{lx} \cdot \mathrm{m}^{2}\right)\right]$ を性能指標としている。これらの規格は, 日射に含まれる近赤外線を測定 対象にしていないだけでなく, 日射反射の観点から必要とされる入射光軸 に一致した反射光, つまり, 入射光のうちどの程度が実際に再帰反射して いるのかということについては，測定法が示されていない。これは，入射 光軸と完全に一致した反射光を光学的に測定することが難しいことに加え, 現在の再帰反射材は, 夜間の視認性を高める目的で使用されており，そこ では, 自動車のヘッドライトによって照射された際に, わずかにずれた角 度のある運転手の目線に対する反射成分こそが, 運転手が感じる明るさ (必 要とされる反射性能）に対応しているからである。つまり，これらの日本 工業規格 ${ }^{1), 2}$ は, 本論文で問題にしている再帰反射成分の日射反射率には直 接は関係しない。ただし，本論文で使用した再州反射材は標識用として市 販されているものであり, JIS Z $8714^{1}{ }^{1}$ に基づく再帰反射係数の值がメーカ 一によって公表されている(試料番号 9 を除く)。参考までに，その值（製 品カタログまたは仕様書で保証されている值）を表 A-1 に示す。

表 A-1 本論文で使用した再帰反射材の再帰反射係数（仕様）

\begin{tabular}{|c|c|c|c|c|c|c|}
\hline 観測角 & 入射角 & 6:プリズム & 7: カプセル & 8: 封入 & 9: 封入 & 10: プリズム \\
\hline \multirow{3}{*}{$12^{\prime}$} & $5^{\circ}$ & 625 & 250 & 140 & - & 800 \\
\hline & $30^{\circ}$ & 325 & 150 & 60 & - & 450 \\
\hline & $40^{\circ}$ & - & 110 & 20 & - & - \\
\hline \multirow{3}{*}{$20^{\prime}$} & $5^{\circ}$ & 500 & 180 & 95 & - & 550 \\
\hline & $30^{\circ}$ & 225 & 100 & 45 & - & 265 \\
\hline & $40^{\circ}$ & - & 95 & 17 & - & - \\
\hline \multirow{3}{*}{$2^{\circ}$} & $5^{\circ}$ & 6.00 & 5.0 & - & - & - \\
\hline & $30^{\circ}$ & 3.75 & 2.5 & - & - & - \\
\hline & $40^{\circ}$ & - & 1.5 & - & - & - \\
\hline
\end{tabular}


注 3）一例を挙げると，入射光軸からわずかにずれた角度における反射成分 (不完全な再帰反射成分) は，運転手が感じる明るさに対応寸るため，視 認性の観点からはむしろ好ましい注2)。よって, 標識用の再帰反射材の中に は，不完全な再帰反射成分がある程度含まれるように，意図的にばらつき を持たせて設計・製造されているものがある。一方, 日射反射の観点から は，適用した面と太陽との間に建物がある場合，光害となる恐れがあるた め，不完全な成分は極力少ない方がよいと考えられる。

注 4）本論文で使用した積分球付属分光光度計は, 積分球内部の鏡面反射条 件の位置に, 光学吸収体が設置できるようになっており, 吸収体の有無に よって, 鏡面反射成分を含めた反射率（吸収体無し）と，含めない反射率 (吸収体有り) との両方を測定することができる。吸収体が有るときに測 定される分光反射率が拡散分光反射率 $\rho \operatorname{Dif}(\lambda)$ であり, 吸収体が有るときと 無いときの反射率の差分が，鏡面分光反射率 $\rho_{\mathrm{Spe}}(\lambda)$ である。

注 5）気象観測に使用した測定機器について, 全天, 天空，直達日射は，英 弘精機製, 精密全天日射計 MS-802, 直達日射計 MS-53を，風速は，KAIJIO Sonic 社製, 超音波風高風速計 SAT-530を, 外気温度・相対湿度は, 神栄テ クノロジー社製，温湿度計 THT-B4T を用いた。これらの観測機器は，大阪 市立大学生活科学部棟屋上 (大阪市住吉区, 北緯 $34^{\circ} 36^{\prime}$, 東経 $135^{\circ} 30^{\prime}$ ) に常設された太陽放射昼光測定システム ${ }^{20), 21)} の 一$ 部であり，その観測地点 近傍に試験試料を設置した。

注 6）試料に入射する日射量 $\mathrm{J}_{\mathrm{i}}\left[\mathrm{W} / \mathrm{m}^{2}\right]$ は, 実測した法線面直達日射量と全天日 射量をPerez/Ineichen モデルに代入して求めた ${ }^{24), 25), 26)}$

$$
J_{i}=J_{D N} \cdot \cos \theta_{i}+J_{S H \theta}+J_{H} \cdot \alpha \cdot \frac{1-\cos \theta_{S}}{2}
$$

$\mathrm{J}_{\mathrm{DN}}$ : 法線面直達日射量 $\left[\mathrm{W} / \mathrm{m}^{2}\right], \mathrm{J}_{\mathrm{SH}_{\theta}}$ : Perez $の$ 斜面日射量 $\left[\mathrm{W} / \mathrm{m}^{2}\right], \mathrm{J}_{\mathrm{H}}$ : 水 平面全天日射量 $\left[\mathrm{W} / \mathrm{m}^{2}\right], \alpha$ : 地物のアルベド係数, $\theta_{\mathrm{i}}$ : 直達日射の試料面 への入射角, $\theta_{\mathrm{S}}$ : 試料の傾斜角。

注 7）試料番号 9 の再帰反射材は, 広角タイプと言われる製品である。表 A-1 に示すように通常の再帰反射材 (9 以外の試料) では入射角が小さい（垂直 入射）ほど，反射輝度が高いのに対して，広角タイプのものは，入射角が 大きい（すれすれ角入射）ほど，反射輝度が高くなるように設計されてい る（ガードレールなど自動車に対して平行に設置する部位に使用されるこ とを想定した製品)。よって，本論文の測定条件である入射角 $7^{\circ}$ では本来 の再帰反射性能が発揮されていないと考えられる。

\section{参考文献}

1）JIS Z 8714-1995 再帰性反射体-光学的測定-測定方法，日本規格協会 1995 2）JIS Z 9117-1984 保安用反射シート及びテープ，日本規格協会 1984

3）酒井英樹, 永村一雄，井川憲男：再帰反射材の日射反射特性（その 1 ）照 り返し抑制効果の実証実験, 日本建築学会学術講演梗概集 D2, pp.111-112, 2007.8

4）酒井英樹, 永村一雄, 井川憲男 : 再帰反射材の照り返し抑制効果, 日本建 築学会構造系論文集第 630 号, pp.1239-1244, 2008.8

5) 藤本哲夫, 岡田朋和, 近藤靖史 : 高反射率塗料の日射反射特性に関する研 究, 日本建築学会環境系論文集, 第 601 号, pp.35-41, 2006.3

6）近藤靖史, 長澤康弘, 入交麻衣子：高反射率塗料による日射熱負荷軽減と ヒートアイランド現象の緩和に関する研究, 空気調和・衛生工学会論文集, Vol.78, pp.17-25, 2000.7

7) Akbari, H.: Cool Roofs Save Energy, ASHRAE Technical Data Bulletin, Vol.14, No.2, pp.1-6, 1998

8) 西岡真稔: 道路舗装による街路の熱環境調整, 環境工学研究 No.253, pp.27-33, 2005.4

9）西岡真稔 : 放射伝熱の観点から見た都市表面の伝熱特性に関する基礎的解 析, 日本建築学会環境系論文集, 第 602 号, pp.61-68, 2006.4

10）近藤靖史, 大木泰祐：クールルーフによるヒートアイランド対策, 建材 試験情報, Vol.42, pp.6-14, 2006.5

11）赤川宏幸，竹林英樹，森山正和：湿潤舗装と遮熱舗装上の温熱環境改善 効果に関する実験的研究, 日本建築学会環境系論文集, 第 623 号, pp.85-91,
2008.1

12）西岡真稔，井上智，中村三智之，中尾正喜，鍋島美奈子：再帰反射を利 用した反射パネルの日射反射特性の分析その 1 数值計算方法と再帰反射 ユニットの基本特性, 日本建築学会学術講演梗概集 D1, pp.663-664, 2006.9

13）酒井英樹, 永村一雄, 井川憲男：分光反射率に基づく建築材料の日射反 射率の測定方法-測定条件の妥当性の検討-, 日本建築学会環境系論文集, 第 616 号, pp.31-36, 2007.6

14）JIS Z 8722: 2000 色の測定方法一反射及び透過物体色，日本規格協会 2000

15) CIE Technical Report, CIE Publication No.15: 2004, Colorimetry, CIE Central Bureau, Vienna, 2004

16）JIS R 3106:1998 板ガラス類の透過率・反射率・放射率・日射熱取得率 の試験方法, 日本規格協会 1998

17）馬場弘，金山公夫，遠藤登，金澤浩志：太場エネルギー利用のための分 光日射量の測定と整理 (第 1 報, Bird のモデルに基づく分光日射特性の比 較)，日本機械学会論文集（B 編）62 巻 559 号, pp.2847-2853, 1996.7

18）一八瀬雅之, 石野久彌, 永田明寛：建材の日射透過および反射性能にお ける分光感度特性, 日本建築学会環境系論文集, 第 583 号, pp.15-21, 2004.9 19）大西晃：宇宙用熱制御材料の太陽光吸収率の入射角依存性と全半球放射 率の温度依存性に関する測定データ, 宇宙科学研究所報告, 第 113 号, pp.1-16, 2000.12

20) Igawa, N. Emura, K. Nimiya, H. and Kikuchi, T.: A Solar Radiation and Daylight Measurement System in Osaka, Japan, 26th Session of the CIE, Beijing, pp. D3.191-D3.194, 2007.7

21）井川憲男, 永村一雄, 二宮秀與, 菊池卓郎：大阪市立大学における太陽 放射昼光測定システム, 日本建築学会大会学術講演梗概集 D1, pp.285-286, 2006.9

22）浦野良美, 中村洋編著 : 建築環境工学 森北出版 1996, p.208, 2004

23）萩島理, 谷本潤, 成田健一: 都市表面の対流熱伝達率に関寸る既往研究 のレビュー, 水文学・水資源学会誌 Vol.17, No.5, pp.536-554

24) R. Perez, P. Ineichen, R. Seals, J. Michalsky, and R. Stewart: Modeling Daylight Availability and Irradiance Components from Direct and Global Irradiance, Solar Energy vol.44,No.5,pp.271-289, 1990

25) P. Ineichen: The Importance of Correct Albedo Determination for Adequately Modeling Energy Received by Tilted Surface, Solar Energy, vol. 39, No. 4, pp. 301-305, 1987

26) N. Igawa, Y. Koga, T. Matsuzawa, H. Nakamura: Models of sky radiance distribution and sky luminance distribution, Solar Energy 77, pp. 137-157, 2004

（2008年 3 月 10 日原稿受理，2008年 6 月27日採用決定） 